\title{
Evli Bireylerin Öznel İyi Olma Düzeylerinin Yordanması ${ }^{1}$
}

\author{
Nergis Canbulat $^{2} \quad$ Zeynep Cihangir Çankaya ${ }^{3}$
}

Geliş Tarihi: 18.11.2014 Kabul Tarihi:15.12.2014

\section{$\ddot{O} \mathbf{z}$}

$\mathrm{Bu}$ araştırma, evlilikte problem çözme becerisi, evlilik doyumu ve kontrol odağ değişkenlerinin evli bireylerin öznel iyi olma düzeylerini yordama gücünü ortaya koymak amacıyla yapılmıştır. Araştırmada veri toplama aracı olarak, Öznel İyi Oluş Ölçeği, Evlilik Yaşamı Ölçeği, Rotter'in İçsel Dışsal Kontrol Odağı Ölçeği, Evlilikte Problem Çözme Ölçeği ve araştırmacı tarafından hazırlanan Kişisel Bilgi Formu kullanılmıștır. Araştırmaya İzmir ilinde yaşayan 317 evli birey (181 kadın, 136 erkek) katılmıştır. Araştırmaya katılan bireylerin en az bir yıllık evli olmaları şartı aranmıştır. Evlilikte problem çözme becerisi, evlilik doyumu ve kontrol odağı değişkenlerinin evli bireylerin öznel iyi olma düzeylerini yordama gücünü ortaya koymak amacıyla aşamalı çoklu regresyon analizi yapılmıştır. Araştırmanın bulguları incelendiğinde; evlilikte problem çözme becerisi, evlilik doyumu ve kontrol odağ 1 değişkenlerinin evli bireylerin öznel iyi olma düzeylerinin anlamlı yordayıcıları olduğu bulunmuştur.

Anahtar sözcükler: Öznel iyi olma, evlilikte problem çözme, evlilik doyumu, kontrol odağ1

\footnotetext{
${ }^{1} \mathrm{Bu}$ araştırma, Yrd. Doç. Dr. Zeynep Cihangir Çankaya'nın danışmanlığında Nergis Canbulat tarafından hazırlanan yüksek lisans tezinin özetidir.

2 Uzman Psikolojik Danışman, Buca Halk Eğitim Merkezi, nergistulek@gmail.com

3 Yrd. Doç. Dr., Ege Üniversitesi Eğitim Fakültesi, zeynep.cihangir.cankaya@ege.edu.tr
} 


\title{
Predicting Subjective Well-Being Levels Married Individuals’
}

Submited by 18.11.2014 Accepted by 15.12.2014

\begin{abstract}
This study was conducted to determine the predictive power of marital problem solving skills, marital satisfaction and locus of control on the subjective well being of married individuals. Subjective Well Being Scale, Marriage Life Scale, Internal-External Locus of Control Scale by Rotter, Marital Problem Solving Scale and The Personal Information Form which was designed by the researcher were used in this study. 317 married individuals (181 women, 136 men) from İzmir, Turkey, constituted the target sample. There was a prerequisite that the individuals participated in this study should be married at least one year with their spouses. In order to determine the predictive power of variables stepwise multiple regression analysis was conducted. The results of this study showed that; marital problem solving skills, marital satisfaction and locus of control were significant in predicting subjective well being of married individuals.

Key words: Subjective well being, marital problem solving skill, marital satisfaction, locus of control
\end{abstract}


Mutluluk, yaşamın birçok alanında bireylerin kendini iyi hissetmesi anlamına gelebilen psikolojik bir güç ve neşe kaynağı olup, insanların tüm yaşamları boyunca arzuladıkları bir durumdur. Mutlu olabilmek iyi bir yaşamın ölçütü olarak kabul edilebilmektedir. Mutluluğun insan hayatındaki önemi araştırmacıları öncelikle mutsuzluğu önleyecek faktörlere, son y1llarda ise mutlululuğu sağlayan faktörlere yöneltmiştir.

Süreç içerisinde ruh sağlığı kapsamında sadece insanları mutsuz eden süreçlere odaklanmanın yetersiz olduğu ve ruh sağlığı çalışmalarının insanlarda olumlu bir değişim yaratan noktalara da odaklanacak şekilde genişletilmesinin önemi ortaya çıkmıştır. Bu görüşü savunan pozitif psikoloji akımıyla dikkatler insan doğasının güçlü yanlarına, olumlu kişisel deneyimlere, olumlu kişisel özelliklere çekilmiştir. Bu akımın etkisiyle mutluluk kavramının da bilimsel araştırmalarda konu olmaya başladığı görülmektedir (Seligman ve Csikszentmihalyi, 2000).

Pozitif psikoloji kapsamında mutluluk, “öznel iyi olma” olarak ele alınmaktadır. Mutlulukla eş değer gibi görünen öznel iyi olma kavramı ilk defa Bradburn (1969) tarafindan ortaya atılmıştır. Bradburn, öznel iyi olmayı, olumsuz duygu ile olumlu duygu arasındaki denge olarak tanımlamıştır. Bu yaklaşımda olumlu duygu; isteklilik, enerjik olma, ruhsal uyarılmışlık ve kararlılık gibi durumları içerirken, olumsuz duygu; üzüntü, kaygı, korku, öfke, suçluluk ve küçümseme gibi hoş olmayan duygu durumlarından oluşmaktadır (Watson, 1988; Watson ve Pennebaker, 1989). Başka bir tanımlamayla öznel iyi olma bireyin yaşamına ilişkin sahip olduğu duygu ve düşüncelerinin genel bir değerlendirmesini, mutluluğu, huzuru, memnuniyeti ve yaşam doyumunu içermektedir (Diener, Oishi ve Lucas, 2003).

Diener (1984), öznel iyi olma kavramı ile ilgili yeni bir paradigma sunarak, öznel iyi olmanın uzman görüşüyle biçimlenen dışsal bir kritere değil, bireyin yaşamındaki kişisel gelişimine dayandığını belirtmiş; öznel iyi olmanın birbiriyle ilişkili ancak birbirinden ayrı olan, öznel değerlendirmeye dayanan duygusal ve bilişsel olmak üzere iki boyuttan oluştuğunu öne sürmüştür. Öznel iyi olmanın duygusal boyutu olan mutluluk ya da duygusal öznel iyi olma düzeyi; bireyin olumlu duygu yaşantısının olumsuz duygu yaşantısından fazla olması ile belirlenir. Öznel iyi olmanın bilişsel boyutu olan yaşam doyumu ise; hayattan, işten, evlilikten, okuldan ya da diğer alanlardan alınan doyuma ilişkin öznel yargılara dayanır. Buna göre mutlu insan, genellikle neşeli, hayatından memnun ve sadece ara sıra üzgün insandır (Biswas-Diener, Diener ve Tamir, 2004; Diener, Suh ve Oishi, 1997). Başka bir ifade ile öznel iyi olma insanın kendisini hem duygusal hem de bilişsel boyutta değerlendirmesini gerektirmektedir. Bu değerlendirme sonunda öznel iyi olma düzeyi yüksek olan yani mutlu 
birey, yaptığı bilişsel değerlendirmeyle yaşamdan doyum aldığı yargısına varacak ve yaşamda kendisine hoşnutluk veren olumlu duyguları, olumsuz duygulardan daha fazla hissedecektir (Diener ve Diener, 1996).

Öznel iyi olmanın bileşenleri olan, olumlu-olumsuz duygulanım ve yaşam doyumunun çeşitli doyum alanları olduğu görülmektedir. Bu doyum alanları; iş, aile, arkadaş ilişkileri, bireyin ait olduğu grup, sağlık, para ve serbest zaman gibi bireyin öznel iyi olma düzeyini arttıran; bunun yanı sıra bireyin ruh sağlığına etki eden alanlardır.

Yaşam doyum alanlarının en önemlilerinden biri kabul edilen evlilik, çeşitli biçimlerde tanımlanmaktadır. Bir erkek ve bir kadın arasında toplum tarafından onaylanmış ilişki (Kottak, 2001); karşı cinsten iki kişinin birlikte yaşamak, yaşantıları paylaşmak, çocuk yapmak ve yetiştirmek gibi amaçlarla yaptıkları bir sözleşme (Özgüven, 2000) bu tanımlardan bazılarıdır. Glenn (1991) evliliği, bireyin mutluluğunu sağlayan ve kişiliğinin gelişiminde önemli rol oynayan bir kurum olarak tanımlamıştır. Fowers (1993) ise evliliği, bireyin benliğini başkasının benliği ile birleştirmesine imkan veren, kişiliğinin gelişmesini ve mutlu olmasını sağlayan bir kurum olarak ifade etmektedir.

Evlilik yaşamıyla, kadın ve erkeğin biyolojik, sosyal ve psikolojik birtakım ihtiyaçları ve güdüleri doyurulmaktadır (Özgüven, 2000). Glen (1990) evliliğin, bireyin yaşam süresini uzattığını, psikolojik ve bedensel sağlığını koruduğunu, mutluluğunu arttırdığını belirtmektedir. Yapılan bazı çalışmalarda, evli olmayanlarla karşılaştırıldığında evli insanların anlamlı olarak daha yüksek düzeyde iyi olma düzeyine (Blanchflower ve Oswald, 2004), daha yüksek yaşam doyumu ve mutluluğa (Selim, 2008) ve en düşük düzeyde ruhsal sıkıntıya sahip oldukları (Clark ve Oswald, 1994) görülmüştür.

Öznel iyi olmanın yapısı, evliliğin tanımları ve ilgili literatür incelendiğinde evlilik ve öznel iyi olmanın örtüşen birçok bileşeninin olduğu görülmektedir. Belirtilen çalışmalarda (Blanchflower ve Oswald, 2004; Clark ve Oswald, 1994; Selim, 2008) da görüldügü gibi evlilik bireylerin hem doyum alanlarından birisidir, hem de öznel iyi olmanın bileşenlerinden olan olumlu-olumsuz duygulanımı etkilemektedir. Bu durum evli bireylerin öznel iyi olma durumlarını etkileyen değişkenlerin ve değişkenlerin öznel iyi olmaya düzeyine katkılarının belirlenmesinin önemini ortaya çıkarmaktadır. $\mathrm{Bu}$ bağlamda bu çalışmada ele alınan değişkenlerden birisi evlilik doyumudur.

Öznel iyi olma ve evlilik ilişkisini inceleyen araştırmaların incelendiği bir çalışmada evlilik ve aile doyumunun yaşam doyumunun en güçlü yordayıcılarından biri olduğu bulunmuştur 
(Diener, 1984). Buna göre evli insanların, hiç evlenmemiş, boşanmış ya da eşini kaybetmiş insanlara göre daha yüksek düzeyde öznel iyi olmaya sahip oldukları; yaş ve gelir gibi değişkenler kontrol altına alındıktan sonra dahi, evliliğin öznel iyi olma ile anlamlı korelasyonlar göstermeye devam ettiği bildirilmektedir (Diener, Suh, Lucas ve Smith, 1999). $\mathrm{Bu}$ araştırma bulgularına paralel olarak evliliğin niteliğinin yaşam doyumuna ve öznel iyi olma düzeyine olumlu katkılar sağladığı söylenebilir. Diener ve diğerlerine (1999) göre mutlu bir evliliğin en büyük yararı, duygusal ve ekonomik destek sağlayarak yaşamın zorluklarına karşı tampon görevi oluşturmasıdır. Argyle (1999), ise evliliğin öznel iyi olmaya etkisinin genel olarak sağladığ 1 toplumsal destek fonksiyonundan kaynaklandığını savunmaktadır (akt. Weiten, Dunn ve Hammer, 2009). Ryan ve Deci (2001) de tek başına medeni durumdan çok ilişki kalitesinin yaşam memnuniyetini tahmin etmede önemli olduğunu bildirmektedirler.

Evli bireylerin kullandıkları problem çözme becerileri ve bu becerilerin eşlerin öznel iyi olma düzeylerini hangi yönde etkilediği konusu ilgili literatürde üzerinde durulan önemli konulardan bir diğeridir. Problem çözme becerisi, kişiyi çözüme götürecek bilgilerin kazanılması ve bu bilgilerin birleştirilerek bir sorunun çözümüne uygulanabilme düzeyi olarak tanımlanmaktadır (Güçlü, 2003). Durlak'ın (1983) da belirttiği gibi, etkin problem çözücüler değişik sosyal şartlara karşı esnek, uyumlu, stresle iyi mücadele eden, kişisel amaçlarına ulaşmak ve ihtiyaçlarını gidermek için uygun metotları geliştirebilen kişilerdir. Tersine etkin problem çözücü olmayanlar, sorunlarla uğraşırken yeterli tepkileri gösteremez ve çevreleriyle yeterince uğraşamazlar (akt. Heppner ve diğ., 2004).

Bireylerin kullandıkları problem çözme yaklaşımları genel psikolojik uyumlarını, akılcı olmayan inançlarını ve işlevsel olmayan düşüncelerini, kişisel sorunlarının sıklığını olumsuz yönde etkilemektedir (Hepner ve diğ., 2004). Etkili problem çözme becerilerine sahip bireyler, sosyal anlamda daha güvenli, daha az stres yaşayan ve sosyal beceri sahibi kişilerdir. Bu durum, onların evlilik ilişkilerine de yansımaktadır. Hünler ve Gençöz (2003), bir evliliğin yürütülmesi sırasında karşılaşılan problemlerin doğru problem çözme stratejileri ile çözülmesinin, ilişki için yapıcı ve olumlu sonuçlar doğuracağını belirtmektedirler. Christian, OLeary ve Vivian (1994) ise uyumsuz eşlerin yaşadığı depresyonun, hem erkek hem de kadındaki zayıf problem çözme becerileri ile ilgili olduğunu, aynı zamanda, problem çözme sırasında sergilenen olumsuz davranışların evlilik doyumu ile ilişkili olduğunu belirtmiştir.

Evli bireylerin öznel iyi olma düzeyleri üzerinde yapılan araştırmalarda ele alınan değişkenlerden bir diğeri de kontrol odağıdır. Rotter (1966) kontrol odağını bireyin kendisini 
iyi ya da kötü olarak etkileyen olayları; kendi yeteneklerine, özelliklerine, kadere ya da güçlü olan başka insanlar gibi değişkenlere bağlama eğilimi olarak tanımlamaktadır. Birey kendi davranışlarının sonucuna bağlı olarak davranıyorsa iç kontrol yönelimli, eğer dış dünyadaki olaylar ve kişilere yönelik davranıyorsa dış kontrol yönelimli olmaktadır şeklinde ifade edilmektedir (Zimbardo, 1985).

Öznel iyi olmanın yapısı ve özellikleri düşünüldüğünde yüksek öznel iyi olma düzeyi ile ilgili yönelimin iç kontrol odağı olduğu görülmektedir. $\mathrm{Bu}$ görüşü destekleyen çalışmalar bulunmaktadır. Yetim (2001)'in belirttiği gibi çeşitli gruplarda ve topluluklarda yapılan çalışmalar, iç kontrol odağı ile öznel iyi olma arasında bir ilişkinin olduğuna işaret etmektedir. Örneğin Tuzgöl-Dost (2006), üniversite öğrencilerinin öznel iyi oluş düzeyleri konulu çalışmasında, iç kontrol odağına sahip öğrencilerin öznel iyi olma düzeylerinin dış kontrol odağına sahip öğrencilerin öznel iyi olma düzeylerinden daha yüksek olduğunu bulmuştur. Birçok çalışmada kişilik etmenlerinin, kontrol odağı, yeterlilik inancı ve başa çıkma stratejileri gibi bilişsel etmenlerle bütünleştiği görülmektedir. Öznel iyi olması yüksek olan bireyler, kendi yaşamlarını denetlediklerine ve kontrol ettiklerine inanmaktadırlar (Myers ve Diener, 1995). Bu bağlamda, kontrol odağının öznel iyi olmanın daha çok bilişsel bileşeni ile örtüşen bir yapı olduğu söylenebilir.

İlgili literatürde de görüldüğü gibi mutlu bir evlilik, bireyin yaşamında önemli bir rol oynamakta ve evli bireylerin psikolojik sağlığını yakından etkilemektedir. Öznel iyi olma ile ilgili yurt içi ve yurt dışında yapılmış birçok araştırma bulunmaktadır. Bu araştırmaların çok büyük bir kısmı, lise ve üniversite öğrencileri üzerinde yapılmıştır. Özellikle, Türkiye'de yapılan çalışmalar incelendiğinde, yetişkinlerin ve evli bireylerin öznel iyi olma düzeylerine ilişkin yapılan bir araştırmaya rastlanmamıştır. Bu durum evli bireylerin öznel iyi olma süreçlerinin incelenmesinin yararını göstermektedir. Bunun yanında problem çözme becerilerinin, kontrol odağının öznel iyi olmayla ilişkisine odaklanan çalışmalar olmasına rağmen, evli bireyler üzerinde yürütülen, evlilik doyumu, problem çözme becerisi, kontrol odağ değişkenlerinin beraber ele alındığ bir araştırmaya rastlanmamıştır.

Boşanmaların giderek arttığı günümüzde evliliğin yapısının, eşler arasındaki ilişkilerin içeriğinin ve özellikle bireylerin evliliklerinden aldıkları doyumun, iyi olmalarını ne düzeyde etkilediğinin anlaşılması çok büyük önem kazanmaktadır. Bunun yanında evlilik, evrensel bir kurum olsa da kültüre özgü bir takım özellikleri içinde barındırmaktadır. Kağıtçıbaşı (1996), ailedeki bireylerin (anne-babaların) kendi rollerini, rollere bağlı değerlerini çok farklı 
algılayabileceğini ve böyle bir durumun kültürden kültüre değişim gösterebileceğini belirtmiştir. Bundan dolayı, bu araştırma kültürümüze özgü olması açısından da önemli ve gerekli görülmektedir. $\mathrm{Bu}$ bağlamda bu araştırmada belirtilen değişkenlerin evli bireylerin öznel iyi olma düzeylerini yordama gücü, başka bir ifade evli bireylerin öznel iyi olma düzeylerini anlamlı bir düzeyde yordayıp yordamadığını belirlemek amaçlanmıştır. Bu araştırma ile elde edilen bulguların öznel iyi olma literatürüne katkı getirmesi ve çift ve ailelerle çalışan psikolojik danışmanlara ışık tutması beklenmektedir.

\section{Yöntem}

\section{Katılımcılar}

Araştırmada iki ayrı çalışma grubu ile çalışılmıştır. Öncelikle “Öznel İyi Oluş Ölçeği”nin yetişkin grubu için geçerlik ve güvenirlik çalışmasını yapmak amacıyla ulaşılabilir örnekleme yöntemi ile İzmir ilinde yaşayan 174 yetişkin bireye ulaşılmıştır. Ölçeğin yetişkin örneklemine uyarlanmasına ilişkin bulgular veri toplama araçları başlığında ilgili kısımda verilmiştir.

Asıl araştırmanın yürütüldüğü çalışma grubu ise, İzmir merkez ilçelerinde yaşayan ulaşılabilir örnekleme yöntemiyle ulaşılan 181 kadın ve 136 erkek olmak üzere 317 evli bireyden oluşmuştur. Araştırma kapsamında incelenen değişkenlerin ölçme kurallarına uygun bir şekilde ölçülebilmesi, ölçülen değişkenlere ilişkin durumların/davranışların evlilikte gözlenebilmesi için evli bireylerin en az bir yıllık evli olmaları kriter olarak alınmıştır. Uygulama çalışmaları Şubat 2011 ve Mart 2011 tarihleri arasında yapılmıştır.

Araştırmaya katılan evli bireylerin yaş ranjı 21-68, yaş ortalaması ise 38,4' tür. Katılımcılara ait eğitim durumları, evlilik süreleri, evlenme usulleri ve çocuk sayıları incelendiğinde, 184’ünün (\% 58) lise 122’sinin (\% 38,5) üniversite ve 11'inin (\% 3,5) yüksek lisans/doktora mezunu olduğu; 79'unun (\% 24,9) 1-5 yıl arası, 60'nın (\% 18,9) 6-10 yıl aras1, 59'unun (\% 18,6) 11-15 y1l aras1, 40’1nın (\% 12,6) 16-20 y1l arası ve 79'unun (\% 24,9) ise 21 yıl ve daha fazladır evli olduğu; 183'ünün (\% 57,7) anlaşarak, 116'sının (\% 36,6) görücü usulü, 18 'inin $(\%$ 5,7) ise diğer (kaçma, töre. vb.) şeklinde evlendiği; 108'inin (\% 34,1) tek çocuğa, 115 'inin (\% 36,3) iki çocuğa, 34'ünün (\% 10,7) ise üç veya daha fazla çocuğa sahip olduğu, 60’ının (\% 10,7) ise hiç çocuğu olmadığ1 görülmüştür. 


\section{Veri Toplama Araçları}

\section{Öznel İyi Oluş Ölçeği (Öİö̈)}

Bireylerin yaşamları hakkındaki bilişsel değerlendirmeleri ile yaşadıkları olumlu ve olumsuz duyguların sıklığı ve yoğunluğunu belirleyerek öznel iyi olma düzeylerini saptamak amacıyla Tuzgöl-Dost (2005) tarafından geliştirilmiştir. Ölçek 46 maddeden oluşmaktadır ve cevaplama sistemi her ifade için "(5) Tamamen Uygun", "(4) Çoğunlukla Uygun", "(3) Kısmen Uygun", "(2) Biraz Uygun" ve "(1) Hiç Uygun Değil" olarak beşli dereceleme tipindedir. Ölçeğin güvenirlik çalışmaları kapsamında Cronbach Alfa güvenirlik katsayısı .93, Pearson momentler çarpım korelasyon katsayısı .86 olarak bulunmuştur. Ölçeğin geçerlik çalışmaları kapsamında faktör analizi, madde toplam korelasyonları ve alt-üst \%27’lik puan grupları incelenmiştir. Faktör analizi çalışmasında ÖİÖ’ne ilişkin KMO katsayısı .861 bulunmuş, Barlett testi anlamlı çıkmıştır. Ölçeğin düzeltilmiş madde toplam korelasyonları incelenmiş, korelasyonlarının .32 ile .63 arasında değiştiği gözlenmiştir. Alt ve üst \%27’lik gruplar arasında yapılan t testi sonucunda gruplar arasında .01 hata düzeyinde önemli fark bulunduğu gözlenmiştir (Tuzgöl-Dost, 2005).

Ölçeğin yetişkinler için geçerlik ve güvenirlik çalışmaları ise bu araştırma kapsamında 174 bireyle yapılmıştır. İlk olarak yapılan faktör analizi çalışmasında ÖÏÖ’ne ilişkin KMO katsayısı .90 bulunmuş, Barlett testi anlamlı çıkmıştır. Faktörlerin her bir değişken üzerindeki ortak varyansının .58 ile .81 arasında değiştiği görülmüştür. Ölçek tek faktörlü modelde sınanmış ve ölçeğin orijinaline bağlı kalmak amacıyla ölçek tek faktörlü olarak kabul edilmiştir. Ölçek maddeleri, ölçeğin güvenirliğini etkileme dereceleri bakımından incelenmiştir. Ayrıca ölçeğin düzeltilmiş madde toplam korelasyonları incelenmiş, korelasyonlarının .25 ile .71 arasında değiştiği gözlenmiştir. Ölçeğin yetişkinler için güvenirlik çalışmasında iç tutarlık katsayısı hesaplanmıştır. Ölçeğin Cronbach Alpha iç tutarlık katsayısı.95 olarak bulunmuştur. Yapılan geçerlik ve güvenirlik çalışmaları incelenip orjinaliyle karşılaştırıldığında, ÖİÖ’nün yetişkin bireyler için uygun olduğu söylenebilir. Ölçekten alınabilecek en düşük puan 46, en yüksek puan 230'dur ve alınan yüksek puan bireyin öznel iyi olma düzeyinin yüksek olduğunu göstermektedir.

\section{Evlilik Yaşamı Ölçeği}


Eşlerin evlilik ilişkisinden sağladıkları genel doyum düzeylerini ölçmek amacıyla kullanılan "Evlilik Yaşamı Ölçeği”, Tezer (1996) tarafından geliştirilmiştir. Ölçek, 10 sorudan oluşan, cevaplama sistemi "kesinlikle katılmiyorum", "katılmıyorum", "kararsızım", "katılıyorum","'”kesinlikle katılıyorum", şeklinde 5'li dereceleme tipindedir. Ölçek, evli ve boşanmış bireylere uygulanmış ve grupların ölçekten aldıkları puan ortalamaları arasında bulunan anlamlı düzeydeki fark $(\mathrm{t}=6.23, \mathrm{p}<0.01)$ ölçeğin d1ş ölçüte göre geçerliğinin kanıtı olarak gösterilmiştir. Ayrıca, "Kişisel Davranış Anketi” puanları ile yapılan karşılaştırma sonucunda bireylerin sosyal beğenirlik yönelimlerinden çok az etkilendiğini göstermiştir $(\mathrm{r}=0.21)$. Ölçeğin, test-tekrar test yöntemi ile belirlenen güvenirlik katsayısı 0.85 , Cronbach Alfa iç tutarlılık katsayısı ise erkek grubunda 0.88, kadın grubunda 0.91 olarak bulunmuştur. $\mathrm{Bu}$ bulgular, ölçeğin güvenilir olduğunu göstermektedir (Tezer, 1996). Bu araştırmadaki Cronbach Alfa iç tutarlık katsayısı .90'dır. Ölçekten alınabilecek en yüksek puan 50, en düşük puan ise 10'dur ve alınan yüksek puan evlilikten yüksek doyum alındığını göstermektedir.

\section{Rotter'in İçel Dışsal Kontrol Odă̆ı Ölçeği (RIDKÖ̈)}

RIDKOÖ (1966), bireylerin genellenmiş kontrol beklentilerinin içsellik dişsallık boyutu üzerindeki konumunu; pekiştiricilerin bireyin kendi içindeki ya da dişındaki güçlerin (şans, kader) kontrolünde olduğuna dair sahip olduğu genel beklenti ya da inancını ölçmektedir. Türkiye'de uyarlama çalışmaları Dağ (1991) tarafindan yapılmıştır. Ölçek 29 maddeden oluşmaktadır ve cevaplama sistemi a ve b olmak üzere iki seçeneklidir.

Ülkemizde yapılan araştırmalarda sıklıkla kullanılan ölçeğin madde-toplam puan korelasyonlarının .11 ile .48 arasında değiştiği bulunmuştur. Basım ve Şeşen (2006) Cronbach Alpha iç tutarlık katsayısının .77; Basım ve Çetin (2010), .74, Küçükkaragöz Sakarya (1998), .65 olduğunu bulmuşlardır. Başka bir çalışmada ise ölçeğin test-tekrar güvenirlik katsayısı .54 olarak bulunmuştur (Küçükkaragöz-Sakarya, 1998). Bu araştırmadaki Cronbach Alpha iç tutarlık katsayısı .61 bulunmuştur.

Ölçekten 0 ile 23 arasında bir toplam puan alınabilmektedir. Alınan yüksek puan bireylerin dış kontrol odağına, düşük puan ise iç kontrol odağına sahip olduklarını göstermektedir. 
Evli bireylerin evlilikte karşılaştıkları problemleri çözme becerilerine ilişkin algılarını belirlemek amacıyla Baugh, Avery ve Sheets-Hawoth tarafından geliştirilmiştir. Ölçeğin Türk kültürüne uyarlama çalışmaları Hünler ve Gençöz ( 2002) tarafından yapılmıştır. Ölçek, 9 maddelik likert tipi bir ölçektir.

Pilot çalışmada ölçeğin iç tutarlığı .88 olarak bulunmuştur $(\mathrm{p}<.001)$. Ölçüt geçerliği için “Çift Uyum Ölçeği” ile olan korelasyonuna bakıldığında ise iki ölçek arasındaki korelasyonu .61 $(\mathrm{p}<.001)$; madde-toplam korelasyonları ise .63 ve .73 arasında bulunmuştur (Hünler ve Gençöz, 2003). Orijinal çalışmada ölçeğin iç tutarlık katsayısı .95; test-tekrar test korelasyon katsayısı .86 $(\mathrm{p}<.001)$ olarak bulunmuştur. $\mathrm{Bu}$ araştırmadaki Cronbach Alfa iç tutarlık katsayısı .93 olarak bulunmuştur. Ölçekten alınabilecek en yüksek puan 45 en düşük puan ise 9'dur. Alınan yüksek puan bireylerin etkili problem çözme becerileri kullandıklarını göstermektedir.

\section{Kişisel Bilgi Formu}

Diğer veri toplama aracı olan "Kişisel Bilgi Formu” evli bireylerin cinsiyet, yaş, eğitim durumu, evlilik süresi, evlenme usulü ve sahip olunan çocuk sayısı bilgilerini elde etmek amacıyla araştırmacılar tarafından hazırlanmıştır.

\section{İşlem Yolu ve Verilerin Analizi}

Araştırma verilerinin toplanması aşamasında ilk olarak, öznel iyi oluş ölçeğinin yetişkin örneklemine uyarlanması amacıyla, Aralık 2010 ve Ocak 2011 tarihleri arasında, 174 yetişkin birey üzerinde bir uygulama gerçekleştirilmiştir.

Araştırmada kullanılan veri toplama araçlarının uygulamaları ise Şubat 2011 ve Mart 2011 tarihleri arasında İzmir ili merkez ilçelerinde yaşayan en az bir yıllık evli olan 317 bireyin katılımı ile gerçekleştirilmiştir. Örneklem belirlenirken ulaşılabilir örnekleme yöntemi kullanılmıştır. Eşlerin araştırmaya katılımları sırasında evli olmaları ve eşleriyle beraber yaşamaları ve en az bir yıllık evli olmaları kriter olarak alınmıştır. Katılımcılardan zarflar içerisinde aldıkları ölçekleri birbirlerinden bağımsız olarak doldurmaları istenmiştir. Veri toplama araçları, çalışmanın amacını, gizliliği, içeren bir yönerge eklenerek verilmiştir.

Verilerin analizinde öncelikle cevap kağıtları kontrol edilmiş ve RİDKOÖ’nün ortaöğretimi bitirmiş kişilere uygulanabilir olması nedeniyle 18, eksik ya da birden fazla seçenek 
işaretlenmiş olma sebebiyle 32 cevap kağıdı değerlendirme dişı bırakılmıştır. Araştırma kapsamında elde edilen veriler, Sosyal Bilimler İstatistik Paket Programı (SPSS, Statistical Package for the Social Sciences)13.0 ile çözümlenmiştir. Araştırmada değişkenler arasındaki ilişkileri belirlemek için korelasyon analizi, bağımsız değişkenlerin öznel iyi olma üzerindeki yordayıcı etkisini ve yordamadaki güçlerini belirlemek için aşamalı çoklu regresyon analizi kullanılmıştır.

Çoklu regresyon analizi, çoklu birlikte değişim, normallik, uç değerler, doğrusallık, homojenlik ve artık değerlerin bağımsızlığı gibi bir takım varsayımlara sahip olduğundan analize geçilmeden önce bu varsayımlar test edilmiştir. Çoklu birlikte değişim, bağımsız değişkenler arasında yüksek düzeyde korelasyon olduğunda meydana gelmektedir (Kalayc1, 2009). Verilerin VIF ve tolerance değerlerine bakılmış ve tolerance değerlerinde .10'dan küçük ve VIF değerlerinde .10'dan büyük değerler gözlenmemiştir. Bu yolla bağımsız değişkenlerin ilişkisiz olduğu saptanmıştır.

Verilerin normal dağılımı Kolmogorov-Smirnov ve Shapiro-Wilk testleri kullanılarak test edilmiştir. Analiz sonuçları anlamlı ise $(\mathrm{p}>$.05) dağılımın normal olmadığ anlamsız çıkması ise dağılımın normal olduğunu gösterir (Kalaycı, 2009). KolmogorovSmirnov testi anlamlı bulunmamıştır ve bu sonuç tüm verilerin normal dağıldığını göstermiştir. Kolmogorov-Smirnov değerlerinin bağımlı ve bağımsız değişkenler için .061 ile .132 arasında değişstiği görülmüştür.

Son test dağılımının çarpıklık ve basıklık düzeyi (skewness ve kurtosis katsayıları) incelendiğinde çarpıklık katsayılarının 062 ile .808 arasında, basıklık katsayılarının ise .052 ile -.659 arasında değiştiği görülmüştür. Bu değerlerin 1'in altında olması dağ1lımın normal normal olduğunu göstermiştir. Tek değişkenli normallik değerleri için $\mathrm{Z}$ değerleri, çok değişkenli normallik ve uç değerleri için Mahalanobis Distance testiyle incelenmiştir. Çok değişkenli normalliği bozan herhangi bir gözleme ve uç değere rastlanmamıştır. Regresyon analizinin yapılması için gerekli olan bütün bu ön analizler sonrasında regresyon analizi için gerekli olan tüm varsayımların karşılandığı görülmüştür.

\section{Bulgular}


Bu bölümde, araştırmaya katılan evli bireylerin öznel iyi olma puanlarına uygulanan aşamalı çoklu regresyon analizi sonuçları verilmiştir. Aşamalı çoklu regresyon analizinde, bağımsız değişkenlerin (evlilik doyumu, evlilikte problem çözme becerisi, kontrol odağı) öznel iyi olma değişkenine etki eden etkileri incelenmiştir.

\section{Korelasyon Analizi}

Araştırmanın bağımsız değişkenleri olan problem çözme becerisi, evlilik doyumu ve kontrol odağı değişkenleri öznel iyi olmayı yordayan değişkenler olarak ele alınmıştır. Regresyon analizini yapabilmek ve anlamlı olan değişkenleri belirlemek amacıyla değişkenlerin birbirleriyle olan korelasyonlarına bakılmıştır.

Tablo 1. Bă̆ımlı ve Bă̆ımsız Değişkenlerin Birbirleriyle Olan Korelasyonları

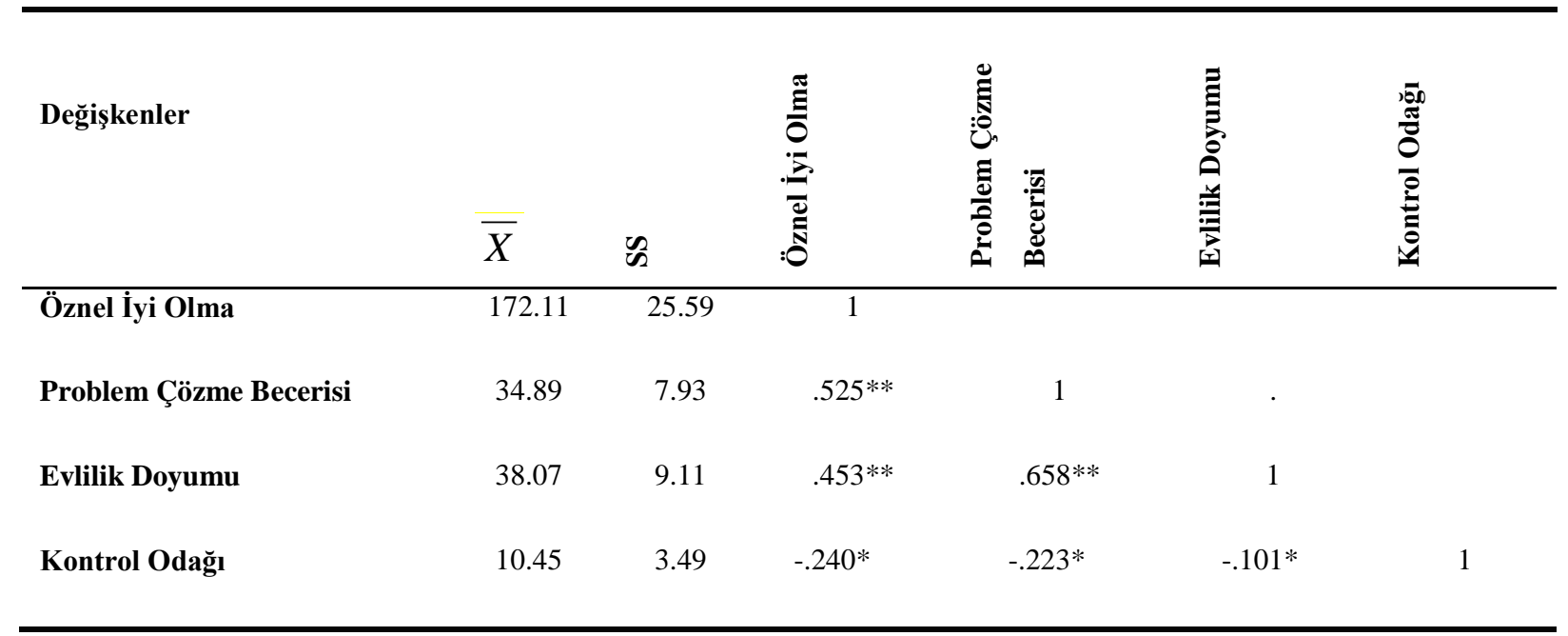

$* * \mathrm{p}<.005 ;{ }^{*} \mathrm{p}<.05$

Tablo 1'de görüldüğü gibi öznel iyi olma ile bağımsız değişkenler arasındaki ikili korelasyonlar anlamlı düzeyde olup, -.24 ile .53 arasında değişmektedir. İyi olma ile problem çözme becerisi arasında olumlu yönde orta düzeyde bir ilişki ( $\mathrm{r}=.53, \mathrm{p}<.005^{* *}$ ), öznel iyi olma ile evlilik doyumu arasında olumlu orta düzeyde bir ilişki ( $\left.r=.45, \mathrm{p}<.005^{* *}\right)$, öznel iyi olma ile kontrol odağı arasında olumsuz yönde düşük bir ilişki ( $r=-.24, \mathrm{p}^{\left.<.05^{*}\right)}$ olduğu görülmektedir.

\section{Regresyon Analizi}


Evli bireylerin problem çözme becerilerinin, evlilik doyumlarının ve kontrol odağ değişkeninin öznel iyi olma düzeylerini yordamadaki güçlerini belirlemek için aşamalı çoklu regresyon analizi uygulanmış ve sonuçları Tablo 2'de verilmiştir.

Tablo 2'de görüldüğü gibi modele giren bağımsız değişkenler öznel iyi olma düzeyini yordamaktadır. Regresyon katsayılarının anlamlılığına ilişkin $t$ değerleri incelendiğinde öznel iyi olmanın yordanmasına en önemli katkının problem becerisi değişkeninden geldiği, bunu sırasıyla evlilik doyumu ve kontrol odağının izlediği görülmektedir. Öznel iyi olmanın yordanmasında modele istatistiksel olarak katkı sunan bağımsız yordama katkılarının ne düzeyde olduğunu belirlemek için $\mathrm{R}^{2}$ değerleri incelendiğinde, "problem çözme becerisi”" değişkenin toplam varyansın \% 27.6'sını açıkladığı görülmektedir.

Tablo 2. Öznel İyi Olma Düzeyini Yordayan Değişkenlere İlişkin Aşamalı Çoklu Regresyon Analizi Sonuçları

\begin{tabular}{|c|c|c|c|c|c|c|}
\hline Değişken & B & Std Hata & Beta & $\mathbf{t}$ & $\mathbf{R}^{2}$ & $R^{2}$ Değişimi \\
\hline \multicolumn{7}{|l|}{ (1. Adım) } \\
\hline (Sabit) & 113.020 & 5.536 & & 20.415 & & \\
\hline Problem Çözme Becerisi & 1.694 & .155 & $.525 *$ & 10.945 & .276 & .276 \\
\hline \multicolumn{7}{|l|}{ (2. Adım) } \\
\hline (Sabit) & 106.759 & 5.844 & & 18.267 & & \\
\hline Problem Çözme Becerisi & 1.290 & .203 & .400 & 6.360 & & \\
\hline Evlilik Doyumu & .534 & .177 & $.190 *$ & 3.026 & .296 & .021 \\
\hline \multicolumn{7}{|l|}{ (3. Adım) } \\
\hline (Sabit) & 120.523 & 7.488 & & 16.095 & & \\
\hline Problem Çözme Becerisi & 1.166 & .205 & .362 & 5.690 & & \\
\hline Evlilik Doyumu & .566 & .175 & .201 & 3.234 & & \\
\hline Kontrol Odağı & -1.019 & .353 & $-139 *$ & -2.889 & .314 & .018 \\
\hline
\end{tabular}


Evlilikte problem çözme becerisi ile öznel iyi olma puanları arasındaki ikili korelasyon pozitif yönde ve anlamlı olarak bulunmuştur $\left(R^{2}=.276, F(1,315)=119.797, p<.05\right)$. İkinci aşamada, problem çözme becerisi değişkenine ek olarak analize "evlilik doyumu” değişkeni sokulmuştur. Bu değişkenin getirdiği ek katkı \% 2.1 olup iki değişken birlikte öznel iyi olma puanlarındaki toplam varyansı \% 29.6'ya yükseltmiştir. Evlilik doyumu değişkeni ve öznel iyi olma arasındaki ikili korelasyon pozitif yönde ve anlamlı bulunmuştur $\left(R^{2}=.296\right.$, $F(1,314)=9.156, p<.05)$. Üçüncü aşamada ise problem çözme becerisi ve evlilik doyumu değişkenlerine ek olarak kontrol odağı değişkeni analize girmiştir. Bu değişkenin getirdiği ek katkı \% 1.8 olup üç değişken birlikte öznel iyi olma puanlarındaki toplam varyansı \% 31.4'e yükseltmiştir. Evli bireylerin kontrol odağı değişkeni ile öznel iyi olma puanları arasındaki ikili korelasyon negatif yönde ve anlamlı bulunmuştur $\left(R^{2}=.314, F(1,313)=8.346, p<.05\right)$.

Aşamalı çoklu regresyon analizi sonuçlarına göre, evli bireylerin öznel iyi olma düzeylerine en önemli yordama katkısının bireylerin problem çözme becerilerinden geldiği, evlilik doyum düzeylerinin ve kontrol odağı değişkeninin izlediği anlaşılmaktadır. Öznel iyi olmanın \%31.4'nün problem çözme becerisi, evlilik doyumu ve kontrol odağı değişkenleri tarafindan açıklandığı görülmektedir.

\section{Tartışma}

Araştırmadan elde dilen bulgularda; evlilikte problem çözme becerisi, evlilik doyumu ve kontrol odağı bağımsız değişkenlerinin evli bireylerin öznel iyi olma düzeylerinin \%31.4’nü açıkladığı ve değişkenlerin yordama katkıları açısından problem çözme becerisi, evlilik doyumu ve kontrol odağı şeklinde sıralandığı görülmüştür.

Bulgular evli bireylerin öznel iyi olma düzeylerinin en güçlü yordayıcısının problem çözme becerisi değişkeni olduğunu göstermektedir. Literatürde doğrudan problem çözme becerisi ve öznel iyi olma ile ilgili çalışmalara rastlanmadığı için araştırma sonucunda elde edilen bu bulgu, problem çözme becerisi ve öznel iyi olma değişkenleri ile ilişkili olduğu düşünülen araştırmalar çerçevesinde tartışılmıştır. Literatürde bireylerin etkili problem çözme becerisine sahip olduklarında, psikolojik uyum düzeylerinin arttığı (Heppner ve Anderson, 1985; Özgüven, Soykan, Haran ve Gençöz, 2003), daha az durumluk ve sürekli kaygı (Nezu, 1985) ve stres yaşadıkları (Zurilla ve Sheedy, 1991), depresyon düzeylerinin azaldığı (Eskin, Ertekin, Harlak, ve Dereboy, 2008), umutsuzluk düzeylerinin düşük olduğu (Yazıcı, 2001) ve 
olumlu benlik kavramına (Heppner, ve diğ., 1983; Ünüvar, 2003) sahip oldukları vurgulanmaktadir.

Bu bulguyu destekleyecek şekilde, Christian ve diğ., (1994), uyumsuz eşlerdeki depresyonun, hem erkek hem de kadın eşteki, daha zayıf problem çözme yeteneği ile ilişkili olduğunu bulmuştur. Buna göre evlilikle ilgili zayıf problem çözme yeteneği, evlilikte stres yaratmanın önemli bir kaynağı olarak görülmektedir. Winemiller ve Mitchel (1994) da, yüksek düzeyde evlilik doyumu yaşayan eşlerin, daha düşük düzeyde evlilik doyumu yaşayanlara göre problemlerinin daha az tekrar ettiğini ve çözümlerinin daha etkin olduğunu belirtmişlerdir. Aynı zamanda bireylerin çözüm üretme ve problem çözme becerilerindeki eksiklikler, hassas konuları tartışma konusunda gösterdikleri duyarlılık nedeniyle, problemlerin tartışılamaması sonucunda, ilişkiyi olumsuz yönde etkilemekte ve evlilik doyumu düşmektedir (Synder, 1997).

Problem çözme becerisinin önemli bir yordayıcısı olmasının nedenleri öznel iyi olmanın yapısıyla da açıklanabilir. Öznel iyi olma düzeyi düşük olan kişinin yaşamından doyum almaması, hoş duygulardan çok öfke, tedirginlik, gerginlik, kaygı ve depresyon gibi olumsuz duyguları yaşaması beklenir (Diener, Suh ve Oishi, 1997). Tam tersi bir biçimde, olumsuz duyguların ve yaşamdan doyum almamanın, öznel iyi olma düzeyini düşüreceği de söylenebilir. Aynı zamanda, bireyler, etkili problem çözme becerilerini kullanmaları sonucunda daha az kaygı, depresyon ve stres yaşamalarıyla öznel iyi olma düzeyleri yükseliyor olabilir. Ayrıca, evlilikte kullanılan problem çözme becerilerinin, problemin yarattığı sıkıntıyı, stresi, depresyonu ve öfkeyi azaltacağı için evliliğin kalitesini de arttıracaktır. Aynı zamanda bireyler çatışma çıkmadan problemi çözümleyebilecekleri için yaşanabilecek stres daha az düzeyde olacaktır. Bu durumun da, evli bireylerin öznel iyi olma düzeylerini olumlu biçimde etkileyebileceği düşünülebilir. Aynı zamanda, doğru ve etkili problem çözme stratejilerinin kullanılmasının bireylerin yaşadıkları ilişki için olumlu ve yapıcı sonuçlar doğurması nedeniyle bireylerin evliliklerinden aldıkları doyum artıyor olabilir.

Araştırmada, evlilik doyumu değişkeninin evli bireylerin öznel iyi olma düzeyinin bir yordayıcısı olduğu ve evli bireylerin evlilik doyumu ile öznel iyi olma düzeyleri arasında pozitif yönde anlamlı bir ilişki olduğu bulunmuştur. Sevgi duygusunun, yakın ilişki ihtiyacının ve sosyal desteğin önemli bir kaynağı olarak ele alınan evliliğin, öznel iyi olma üzerindeki olumlu etkisi, araştırma sonuçlarında tutarlı bir biçimde tekrar eden bir bulgu 
olarak ortaya konmaktadır. Araştırmanın bu bulgusunu destekleyecek bir biçimde Yetim (2001) evliliğin, aile yaşamının birey yaşamındaki kalıcı etkilerinden dolayı, genel iyi olmayı etkilediğini, evlilik ve aileden alınan doyumun, iyi olmanın en önemli öngörücülerinden biri olduğunu vurgulamaktadır. Öznel iyi olma ve evlilik ilişkisini ele alan araştırmalarda da, evlilik ve aile doyumunun yaşam doyumunun en güçlü yordayıcılarından biri bulunduğu görülmektedir (Diener, 1984). Argyle (1999), evliliğin öznel iyi olmaya etkisinin genel olarak sağladığı toplumsal destek fonksiyonundan kaynaklandığını savunmaktadır (akt. Weiten, ve ark., 2009). Ryan ve Deci (2001) de tek başına medeni durumdan çok ilişki kalitesinin yaşam memnuniyetini tahmin etmede önemli olduğunu bildirmektedirler. Hawkins (2005) ise yaptığ1 araştırmada, mutsuz bir evliliği sürdürmenin genel mutluluk, yaşam doyumu, benlik saygısı ve genel sağlıkla olumsuz yönde ilişkili olduğunu bulmuştur.

Yapılan araştırmalar, sağlam ve doyum seviyesi yüksek bir evlilik birlikteliğinin, bireyin hem fiziksel hem de ruhsal sağlı̆̆ını desteklediğini ortaya koymaktadır. Karşılıklı olarak yüksek evlilik doyumuna sahip çiftlerin sahip oldukları yüksek doyumun kendilerine pek çok fayda sağladığı görülmektedir. Evlilik doyum düzeyleri yüksek olan çiftlerin stres seviyeleri düşük, mutluluk düzeyleri yüksek ve olumsuz yaşam koşullarına karşı dayanıklılıkları daha fazla olduğu bilinmektedir. Stresli evlilik yaşamında evlilik doyum düzeyi düşük olan eşlerin, akı1 ve fiziksel sağlıkları risk altında bulunmakta, hatta aynı riski çocukları dahi taşımaktadır (Kirby, 2005).

Elde edilen bulgular ve yapılan araştırmalar incelendiğinde, evlilik doyumunun artmasıyla evli bireylerin öznel iyi olma düzeylerinin de paralel olarak artması, bireylerin evliliklerinden aldıkları doyumun öznel iyi olma düzeylerine büyük oranda katkı sağladığını göstermektedir. Evlilik ilişkisinde eşlerin birbirlerine destek olmaları, sevgi ihtiyaçlarını ve aynı zamanda psikolojik birçok ihtiyaçlarını karşılayabileceği için öznel iyi olma düzeylerini de arttırabilir. Yetim (2001)'in belirttiği gibi ereksel kurama göre; birey amaçlarına ulaştığında ve ihtiyaçları karşılandığında öznel iyi olma düzeyi de artar. Bu bulgu ve bilgilerden hareketle, evlilikten sağlanan doyumun bireylerin öznel iyi olma düzeyi arttıran bir yapı olduğu ve evliliğin bireyin yaşamında bir tampon görevi gördüğü söylenebilir.

Araştırmada, kontrol odağı değişkeninin evli bireylerin öznel iyi olma düzeyinin bir yordayıcısı olduğu ve evli bireylerin kontrol odağı ile öznel iyi olma düzeyleri arasında negatif yönde anlamlı bir ilişki olduğu bulunmuştur. Bu araştırma bulgusunu destekleyecek şekilde Tuzgöl-Dost'un (2006) üniversite öğrencileri üzerinde yaptığı çalışmada da iç kontrol 
odağına sahip öğrencilerin öznel iyi olma düzeylerinin diş kontrol odağına sahip öğrencilerinin öznel iyi olma düzeylerinden daha yüksek olduğu sonucuna ulaşılmıştır.

Literatür incelediğinde, dış kontrol odaklı bireylerin olumsuz olayların gerçekleşmesini engelleyemeyecekleri düşüncesiyle, iç kontrol odaklı bireylere oranla daha fazla kaygı, stres ve depresyon yaşadıkları görülmüştür. İç kontrol odaklı bireyler, olayların sorumluluklarını alıp başarı veya başarısızlıkta neden olarak kendilerini görürler. Dış kontrol odaklı bireyler ise başarı ve başarısızlık durumlarını hep kendileri dışındaki faktörler ile ilişkilendirme yaparak başarısızlıklarda diğerlerini suçlarlar ve dış faktörleri sorumlu tutarlar. Bu durumda, bireyler kısa süreli bir stres durumu yaşarlar (Solmuş, 2004) .Öznel iyi olmanın kaygı, stres ve depresyon ile negatif yönde bir ilişki içinde olduğu düşünüldüğünde, araştırmadan elde edilen bulgu anlamlı bir hale gelmektedir.

Camp ve Ganong (1997), uzun süreli evliliklerde evlilik doyumu ve kontrol odağı arasındaki ilişkiyi araştıran bir araştırma yürütmüşlerdir. $\mathrm{Bu}$ araştırma sonucunda iç kontrol odağına sahip bireylerin, evlilik ilişkilerinde daha doyumlu oldukları bulunmuştur. Yapılan bu araştırmadaki sonuçla birlikte, evliliğin bireylerin önemli yaşam doyum alanlarından olması ve iç kontrol odaklı bireylerin evliliklerinden daha fazla doyum almasıyla bireylerin öznel iyi olma düzeylerinin de artacağı söylenebilir.

Araştırmada elde edilen bu bulgu kontrol odağı ve öznel iyi olma kavramlarının yapısıyla da açıklanabilir. İç kontrol odağına sahip evli bireyler, duygularını daha iyi ifade edebildikleri ve olayların sebeplerini içsel faktörlere yükledikleri için evliliğin niteliği de bu özelliklerden olumlu yönde etkilenebilir. Bireyler evlilik ilişkisinde duygu ve düşüncelerini ifade ettikleri için daha az kaygı ve stres yaşayabilirler. Böylece olumlu duygulanım daha fazla oluşabilir. Evlilikte bireyler etkileşim halinde oldukları için bu gibi özellikler hem evliliği, hem de evliliğin öznel iyi olmayı olumlu yönde etkilemesini sağlayabilir.

Özetle, evlilik ve ailenin kültürümüzde önemi düşünüldüğünde evli bireylerin öznel iyi olma düzeylerini etkileyen değişkenler Türkiye'de incelenerek alana kültürel bağlamda bir katkı sağlanmıştır. Ancak bu araştırma bu konuda ülkemizde yapılan ilk ve tek araştırma olduğu için bu bulgunun yeni araştırma bulgularıyla desteklenmesi yararlı olacaktır. Ayrıca araştırmada Tuzgöl-Dost ( 2005) tarafından üniversite öğrencileri için geliştirilen Öznel Iyi Oluş Ölçeği'nin yetişkin örneklemine uyarlama çalışmasının yapılması araştırmanın bir diğer katkısı olarak düşünülebilir. 
$\mathrm{Bu}$ araştırma araştırmaya katılan evli bireylerin çift olarak alınmaması, evli olmayan bireylerle karşılaştırma yapılmaması gibi bazı sınırlılıklara sahiptir. Bundan sonraki çalışmalarda araştırmaya katılan bireylerin çift olarak dahil edilmesi, evli bireylerin öznel iyi olma süreçlerinin başka değişkenlerle ilişkisi incelenmesi ve bu araştırmadaki model ya da yeni modeller evli olmayan, flört eden, ayrılık sürecinde olan bireylerle karşılaştırılarak önemli bulgular elde edilebileceği önerilmektedir. Araştırmadan elde edilen bulgular doğrultusunda çiftler ve ailelerle çalışan uygulayıcılar aile üyelerinin problem çözme becerilerinin ve içsel kontrol odağı yöneliminin geliştirilmesi için planlamalar yapılması, araştırmacıların bu bağlamda deneysel çalışmalar yürütmesi önerilebilir. Ayrıca bu araştırmada çalışma grubunun özellikleri olan cinsiyet, yaş, eğitim durumu, evlilik süresi, evlenme usulü, çocuk sayısı gibi sosyo-demografik değişkenler dikkate alınmamıştır. Bundan sonra yapılacak olan araştırmalarda sosyo-demografik değişkenlere ilişkin farklılıklar ortaya konulabilir.

Son olarak psikolojik danışma hizmetlerinin hem geliştirici hem de önleyici rolü dikkate alındığında, öznel iyi olma süreçlerinin psikolojik danışma uygulamaları içindeki önemi daha da belirginleşmektedir. Psikolojik danışmanların en önemli görevlerinden birisi danışanın iyi olma düzeyini arttırmasına ve korumasına destek olmaktır. Psikolojik danışma yardımı almak üzere başvuran kişiyi güçlendirmenin amaçlandığı psikolojik danışma sürecinde, öznel iyi olma düzeyinin artmasında etkili olabilecek tüm bilgiler önemlidir. Bu bakış açısından yola çıkarak, danışanlara yardım etmede bu çalışmanın bulgularından ve değişkenlerinden yararlanılabilinir. Ek olarak, çiftlerle ve ailelerle çalışan psikolojik danışmanlar, araştırmanın bulgularından yararlanarak evli çiftlerin öznel iyi olma düzeylerini artıracak psikoeğitim programlarının geliştirilmesi ve programda problem çözme becerilerine yer verilmesi önerilmektedir. 


\section{Kaynakça}

Basım, H.N., ve Çetin, F. (2010). Yetişkinler için psikolojik dayanıklılık ölçeğinin güvenirlik ve geçerlilik çalışması. Türk Psikiyatri Dergisi, 22, 1-13.

Basım, H.N., Şeşen, H. (2006). Kontrol odağının çalışanların nezaket ve yardım etme davranışlarına etkisi: Kamu sektöründe bir araştırma. Selçuk Üniversitesi Sosyal Bilimler Enstitüsü Dergisi, 23, 159-168.

Biswas-Diener, R., Diener, E., ve Tamir, M. (2004). The psychology of subjective well-being. Daedalus, 133(2), 18-26.

Blanchflower, D. G. ve Oswald, A. J. (2004). Well-being over time in Britain and the USA. Journal of Public Economics, 88, 7-8, 1359-1386.

Bradburn, N. (1969). The Structure of Psychological Well-Being, Chicago: Aldine.

Camp, P.L. ve Ganong, L.H. (1997). Locus of control and marital satisfaction in long-term marriages. Families In Society, 78, 624-631.

Christian, J.L., OLeary K. L. ve Vivian, D. (1994). Depressive symtomology in marital discordant women and men: The role of individiul and relationship variables. Journal of Family Psychology, 8, 32-42.

Clark, A. E. ve Oswald, A. J. (1994). Unhappiness and unemployment. Economic Journal, 104, 648-659.

Dağ, İ. (1991). Rotter'in iç-dış kontrol odağı ölçeği (RIDDKOÖ)'nin üniversite öğrencileri için güvenirliği ve geçerliği. Psikoloji Dergisi, 7(26), 10-16.

Diener, E. (1984). Subjective well-being. Psychological Bulletin, 95,542-575.

Diener, E. ve Diener, C. (1996). Most people are happy, Psychological Science, 7, 181-185.

Diener, E., Suh, E. ve Oishi, S. (1997). Recent findings on subjective well- being. Indian Journal of Clinical Psychology, 24, 25-41.

Diener, E., Suh, E., Lucas, R. E. ve Smith, H. L. (1999). Subjective well-being: Three decades of progress, Psychological Bulletin, 125, 276-302.

Diener, Ed., Oishi, S. ve Lucas, E. (2003). Personality, culture and subjective well- being: Emotional and cognitive evaluations of life. Annual Review of Psychology.

Eskin, M., Ertekin, K., Harlak, H., ve Dereboy, Ç. (2008). Lise öğrencisi ergenlerde depresyonun yaygınlığı ve ilişkili olduğu etmenler. Türk Psikiyatri Dergisi, 19, 382389.

Fowers, B.J. (1993). Psychology as public philosophy: An illustration of the moral dimension of psychology with marital research. Journal of Theoretical and Philosophical Psychology, C.13, ss: 124-136.

Glenn, N. D. (1990). Quantitative research on marital quality in the 1980s: A critical review. Journal of Marriage and The Family, 52, 818-831.

Glenn, N. D. (1991). The recent trend in marital success in the United States. Journal of Marriage and The Family, 53, 261-270.

Güçlü, N. (2003). Lise müdürlerinin problem çözme becerisi. Milli Eğitim Dergisi, 160.

Hawkins, D.N. (2005). Unhappily ever after: Effects of long-term, low quality marriages on well-being. Social Forces, 84 (1), 451-471.

Heppner, P.P., Reeder, B.L., ve Larson, L.M. (1983). Cognitive variables associated with personel problem-solving appraisal: Implications for counseling. Journal of Counseling Psychology, 30(4), 537-545.

Heppner P. P., ve Anderson W. P. (1985). The relationship between problem-solving selfappraisal and psychological adjustment. Cognitive Therapy and Research, 9(4), 415427. 
Heppner ,P., Withy, T.E., Dixson, W.E., Suzuki, L.A., Ahluvalia, M.K., O’Neil, J.M., Lucas, M.S., Lopez, S.J., Janowsky, K.M. ve Helms, J.E. (2004). Problem solving and human adjestment. The Counselling Psychologist. 32 (3), 341-484.

Hünler, O.S. ve Gençöz, T. (2003). Boyun eğici davranışlar ve evlilik doyumu ilişkisi. Türk Psikoloji Dergisi, 18 (51),99-108.

Kağıtçıbaşı, Ç. (1996). Ailenin Çeşittiliği. Insan Aile Kültür. Remzi Kitabevi. 3. Basım. İstanbul.

Kalaycı, Ş. (2009). Spss Uygulamalı Çok Değişkenli İstatistik Teknikleri. Asil Yayın Dağıtım. 4. Bask1. İstanbul.

Kirby, J.S. (2005). A study of the marital satisfaction levels of participants in a marriage education course. Unpublished Doctoral Dissertation, Department of Educational Leadership and Counseling Department, University of Louisiana, Monroe.

Kottak, C.P. (2001). Antropoloji: İnsan Çeşitliliğine Bir Bakış, Ankara: Ütopya Yayınevi.

Küçükkaragöz Sakarya, H. (1998). İlkokul ögretmenlerinde kontrol odağl ve ögrencilerinin kontrol odağının oluşumuna etkileri. Yayımlanmamış doktora tezi, Dokuz Eylül Üniversitesi, İzmir. YÖK Ulusal Tez Merkezi veri tabanından elde edildi. (Tez no: 72893).

Myers, D.G., ve Diener, E. (1995).Who is happy?. Psychological Science, 6(1), 10- 19.

Nezu, A.M. (1985). Differences in psychological distress between effective and ineffective problem solvers. Journal of Counseling Psychology, 32(1), 35-138.

Özgüven, İ.E. (2000). Evlilik ve Aile Terapisi. Ankara: Pdrem Yayınları.

Özgüven, H.D., Soykan, Ç., Haran, S., ve Gençöz, T. (2003). İntihar girişiminde depresyon ve kaygı belirtileri ile problem çözme becerileri ve algılanan sosyal desteğin önemi. Türk Psikoloji Dergisi, 18(52), 1-11.

Rotter, J. B. (1966). Generalized expectancies for internal and external control of reinforcement. Psychological Monographs, 80, 1-28.

Ryan, R. M., ve Deci, E. L. (2001). To be happy or to be self-fulfilled: A review of research on hedonic and eudaimonic well-being, In S. Fiske (Ed.), Annual Review of Psychology 52; 141-166. Palo Alto, CA: Annual Reviews, Inc.

Seligman, M. E. P., ve Csikszentmihalyi, M. (2000). Positive psychology: An introduction. American Psychologist, 55(1), 5-14.

Selim, S. (2008). Life satisfaction and happiness in turkey, Social Indicators Research, 88, $531-562$.

Solmuş, T. (2004). İş yaşamı, denetim odağı ve beş faktörlük kişilik modeli. Türk Psikoloji Bülteni, 10, 196-205.

Synder, D.K. (1997). Marital Satisfaction Inventory, Revised (MSI-R) Manual. Published by Western Psychological Services, Los Angeles.

Tezer, E. (1996). Evlilik ilişkisinden sağlanan doyum: Evlilik yaşamı ölçeği. Psikolojik Danışma ve Rehberlik Dergisi, 2, 7, 1-7.

Tuzgöl Dost, M. (2005). Öznel iyi oluş ölçeği’nin geliştirilmesi: Geçerlik güvenirlik çalışması. Türk Psikolojik Danışma ve Rehberlik Dergisi, 3(23), 103-110.

Tuzgöl Dost, M. (2006). Subjective well-being among university students. Hacettepe Üniversitesi Eğitim Fakültesi Dergisi,31, 188-197.

Ünüvar, A, (2003). Çok yönlü algılanan sosyal desteğin 15- 18 yaş arası lise ögrencilerinin problem çözme becerisine ve benlik saygısına etkisi. Yayınlanmamış Yüksek Lisans Tezi. Selçuk Üniversitesi, Konya. YÖK Ulusal Tez Merkezi veri tabanından elde edildi. (Tez no:123194). 
Watson, D., (1988). Intraindividual and interindividual analyses of positive and negative affect: Their relation to health complaints, perceived stress, and daily activities, Journal of Personality and Social Psychology, 54 (6), 1020-1030.

Watson, D., Pennebaker, J. W., (1989). Health complaiments, stress, and distress: Exploring the central role of negative affectivity, Psychological Review, 96 (2), 234-254.

Weiten, W., Dunn, Dana S., ve Hammer, E.Y. (2009). Psychology applied to modern life: Adjustment in the 21st century. (10. Bask1). Wadsword, Cengage Learning.

Winemiller, D.R., ve Mitchell, M.E. (1994). Development of a coding system for marital problem solving efficacy. Illinois Institute of Technology, Department of Psychology, IIT Center, Chicago, IL 60616, U.S.A.

Yazıc1, H. (2001). Üniversite öğrencilerinde uyuma dönük başa çıkma davranışları, umutsuzluk ve problem çözme becerileri, VI. Ulusal ve Psikolojik Danışma ve Rehberlik Kongresi Bildiri Özetleri Kitabı, Türk Psikolojik Danışma ve Rehberlik Derneği, Ankara.

Yetim, Ü. (2001). Toplumdan bireye insan resimleri. İstanbul: Bağlam Yayıncılık.

Zimbardo, R., (1985). www.queendom.com/tests/personality/lc_access.html. adresinden 3 Aralık 2010'da elde edildi.

Zurilla, T. J., ve Sheedy, C. F. (1991). Relation between social problem solving ability and subsequent level of psychological stress in college students. Journal of Personnel Social Psychology, 61(5), 841- 846. 